Rasmussen, B., et al., 2020, U-Pb dating of overpressure veins in late Archean shales reveals six episodes of Paleoproterozoic deformation and fluid flow in the Pilbara craton: Geology, v. 48, https://doi.org/10.1130/G47526.1

\title{
U-Pb dating of overpressure veins in late Archean shales reveals six episodes of Paleoproterozoic deformation and fluid flow in the Pilbara Craton
}

Birger Rasmussen, Jian-Wei Zi, Janet R. Muhling, Daniel Dunkley, Woodward W. Fischer

\section{Drill-hole information}

Samples were collected from two drill-holes from the southern Pilbara Craton, Western Australia (Fig. 1A). Drill-hole ABDP9 was drilled in 2004 as part of the Deep Time Drilling Project (DTDP) of the Astrobiology Drilling Program (ADP) of the NASA Astrobiology Institute (NAI) (Anbar et al., 2007). The project also involved the University of Western Australia, Hamersley Iron, SIPA Resources International, Geological Survey of Western Australia and Randolph Resources. The aim of the drillhole was to "obtain drill core free of modern contamination and weathering effects for biogeochemical analysis to characterize the nature of life and its environment in the late Archean, shortly before the rise of atmospheric oxygen" (Anbar et al., 2007). The drill-hole, which was located at $21^{\circ} 59^{\prime} 29.5$ " S, $117^{\circ} 25^{\prime} 13.6$ " E, recovered $\sim 1000 \mathrm{~m}$ of core spanning the base of the Dales Gorge Member of the Brockman Iron Formation to the Paraburdoo Member of the Wittenoom Formation (Fig. 1B). One half of the core is stored at the School of Earth and Space Exploration at Arizona State University, USA, whereas the other half is archived at the Perth Core Library in Western Australia.

Drill-hole DDH186 was drilled in 1977 by Hamersley Exploration Pty Ltd to target the Marra Mamba Iron Formation (Davy and Hickman, 1988). Drill-hole DDH186 intersected the lower part of the Marra Mamba Iron Formation (Hamersley Group) and the upper part of the Roy Hill Shale Member (Fortescue Group). The location of the drill-hole is shown in Figure 1A (117" 55' E and 22" 24' S; AMG SF50, 594600E and 7522600N). DDH186 was drilled to $207.5 \mathrm{~m}$ normal to the bedding and unweathered rocks were recovered between $54.0 \mathrm{~m}$ and $207.5 \mathrm{~m}$. Samples used in this study were collected from the Roy Hill Shale Member, between $141.95 \mathrm{~m}$ to $207.50 \mathrm{~m}$.

\section{SHRIMP mount identification}

1. Mount BR13-20, plugs C, I \& L (vein), H (detrital); ABDP9 135.02-.10 m - monazite in vein

2. Mount BR13-13, plugs C \& F; ABDP9 141.87-.94 m - xenotime in sigmoidal lenses

3. Mount BR13-13, plugs A, B, D \& E; ABDP9 182.12-.25 m - monazite in vein

4. Mount BR13-20, plugs E \& K; ABDP9 243.20-.30 $\mathrm{m}$ - monazite in vein

5. Mount BR13-20, plug F; ABDP9 333.42-.45 m - monazite, xenotime in matrix

6. Mount BR13-20, plugs A, B, D \& J; ABDP9 364.03-.22 $\mathrm{m}$ - monazite in vein

7. Mount BR19-02, plugs C \& D; DDH186, $183.00 \mathrm{~m}$ - monazite in vein

\section{U-Pb analytical procedures}

Monazite and xenotime were analysed for $\mathrm{U}-\mathrm{Pb}$ dating with the Sensitive High-Resolution Ion MicroProbe (SHRIMP-II) instrument at the John De Laeter Centre, Perth, Western Australia. Grains for analysis were identified in polished thin sections, and $3 \mathrm{~mm}$ diameter plugs were extracted from the thin sections with a hollow-core rotary drill and mounted in $25 \mathrm{~mm}$ diameter epoxy discs. The mounts were cleaned and gold coated before each analytical session. Monazite and xenotime standards were set 
into separate mounts and gold coated simultaneously with sample mounts. Standard and sample mounts were loaded together into the SHRIMP for concurrent analysis during each of the four analytical sessions.

Instrument setup followed protocols for small-spot, in-situ analysis of monazite and xenotime developed in Rasmussen et al. (2001), Fletcher et al. (2000; 2004; 2010). A primary beam of $\mathrm{O}_{2}{ }^{-}$ions was focused through a $50 \mu \mathrm{m}$ Kohler aperture to produce an oval $10 \mu \mathrm{m}$ wide spot on the sample surface with a current of $0.3 \mathrm{nA}$. The secondary ion system was focused through a $100 \mu \mathrm{m}$ collector slit onto an electron multiplier to produce mass peaks with flat tops and a mass resolution of $>5400$ in all sessions. Background counts from scattered ions were reduced using a flight retardation lens, which is known to cause slight session-dependent instrumental mass fractionation (IMF) of $\mathrm{Pb}$ isotopes (Rasmussen et al., 2008). IMF corrections were applied to all analyses.

Data were collected in sets of 8 scans, with standard monazite or xenotime analysed every 4-6 sample analyses. Count times per scan for Pb isotopes 204, background position 204.045, 206, 207 and 208 were 10s, 10s, 10s, 30s and 10s, respectively. Monazite was analysed with a 13-peak run table as defined in Fletcher et al. (2010), which includes mass stations for the estimation of $\mathrm{La}, \mathrm{Ce}$ and $\mathrm{Nd}$ $\left(\mathrm{REEPO}_{2}{ }^{+}\right)$, and $\mathrm{Y}\left(\mathrm{YCeO}^{+}\right)$. Measurements on monazite standards FRENCH, Z2234 and Z2908 (see Fletcher et al., 2010 for details) were done concurrently for $\mathrm{Pb} / \mathrm{U}$ and $\mathrm{Pb} / \mathrm{Th}$ calibration (FRENCH), 204 a.m.u. isobar corrections, IMF corrections and matrix corrections required for variable U, Th, Y and $\mathrm{Nd}$ contents. Raw data were processed using a customised task file for the SQUID2 (v. 2.50.12.03.08) add-in for Excel 2003 (Ludwig, 2009), and plotted using the ISOPLOT (v. 3.76.12.02.24) add-in (Ludwig, 2008). Common $\mathrm{Pb}$ corrections were made from ${ }^{204} \mathrm{~Pb}$ measurements corrected for the 204 a.m.u isobar, following the procedure in Fletcher et al. (2010). Common $\mathrm{Pb}$ composition was assumed to be that of Broken Hill lead, a common environmental contaminant in Australia, with a composition equivalent to that at $1.6 \mathrm{Ga}$ in the two-stage evolution model of Stacey and Kramers (1975). Since all analyses have low ${ }^{204} \mathrm{~Pb}$ contents and yield mid to late-Proterozoic ${ }^{207} \mathrm{~Pb} /{ }^{206} \mathrm{~Pb}$ ages, the choice of Broken Hill lead as common $\mathrm{Pb}$ will not have significant effects on results. IMF and matrix corrections were done using an Excel spreadsheet developed by I. R. Fletcher.

Xenotime was analysed with a 9-peak run table following analytical protocols in Fletcher et al. (2000, 2004). $\mathrm{Pb} / \mathrm{U}$ calibrations and matrix corrections for $\mathrm{U}$ and $\mathrm{Th}$ contents were based on concurrent measurements of the standards MG-1 (Fletcher et al., 2004) and z6413 ("Xeno1"; Stern and Rayner, 2003). $\mathrm{Pb} / \mathrm{Th}$ was determined indirectly, using a fixed $\mathrm{Th} / \mathrm{U}$ calibration (Fletcher et al., 2004). Matrix corrections for REE assumed the samples to have REE abundances similar to Xeno1. Matrix corrections were done using an Excel spreadsheet developed by I. R. Fletcher.

Data are presented in table with $1 \sigma$ errors. Individual analysis errors are quoted in text at $1 \sigma$, and pooled ages are quoted in text and figures at $95 \%$ confidence levels. A minimum spot-to-spot external precision of $1 \%(1 \sigma)$ was assumed for standard analyses in all sessions and propagated to U-Pb measurements on all samples of both monazite and xenotime. Data were collected during four sessions, including one session for xenotime analysis. The sessions are indicated in the data table. The following precisions on mean calibration values were obtained in each session: session 1 (monazite) $=0.3 \%(n=$ 10 , MSWD $=1.1$, external precision $=1.0 \%)$, session 2 (xenotime $)=0.8 \%(n=7, \operatorname{MSWD}=3.3$, external precision $=1.6 \%)$, session $3($ monazite $)=0.3 \%(n=6$, MSWD $=1.6$, external precision $=$ $1.0 \%)$ and session $4($ monazite $)=0.6 \%(n=10$, MSWD $=4.3$, external precision $=1.5 \%)$. 


\section{Sample descriptions and results}

ABDP9 87B, 135.02-.1 m (Mount McRae Shale)

In this sample, four discrete grains of monazite were identified and analysed; three from a vein and one from the finer-grained matrix. All grains are less than $50 \mu \mathrm{m}$ across, irregular and inclusion-rich. Analyses on all grains have low $U(<200 \mathrm{ppm})$, whereas Th is much higher in the matrix-hosted grain (3.0-4.2\%) than in the vein-hosted grains (359-4164 ppm). Two analyses on the matrix-hosted grain yielded consistent, slightly discordant data with a mean ${ }^{207} \mathrm{~Pb} /{ }^{206} \mathrm{~Pb}$ age of $2514 \pm 18 \mathrm{Ma}(n=2$, MSWD $=0.67)($ Fig. 3A, Table DR1). Ten analyses from the three vein-hosted grains yield variably discordant data with consistent ${ }^{207} \mathrm{~Pb} /{ }^{206} \mathrm{~Pb}$ ages, with a mean ${ }^{207} \mathrm{~Pb} /{ }^{206} \mathrm{~Pb}$ age of $2192 \pm 24 \mathrm{Ma}(n=9$, MSWD $=1.00)$. Both ages are interpreted as dating monazite growth, with the older matrix age possibly including a detrital component.

\section{ABDP9 86A, 141.87-.94 m (Mount McRae Shale)}

Three grains of xenotime were identified and analysed in this sample. All three are platy poikiloblasts up to $250 \mu \mathrm{m}$ across, aligned parallel to bedding. Grain edges are ragged and inclusions are in most cases also aligned with bedding, typical of growth overprinting the rock fabric. In grain BR13-13C.1, inclusions occur as flakes aligned perpendicular to the length of the grain. Grain BR13-13C.2 is lensshaped, and has margins intergrown with nickel sulfide. Analyses contain around 500-900 ppm U and 2700-9000 ppm Th. Six out of seven analyses on grain BR13-13C.2, excluding one concordant analysis with a slightly younger age, yield a mean ${ }^{207} \mathrm{~Pb} /{ }^{206} \mathrm{~Pb}$ age of $2043 \pm 11 \mathrm{Ma}(n=6, \mathrm{MSWD}=0.8)$ (Fig. $3 \mathrm{~B}$, Table DR2). Analyses on the other two grains yield a mean ${ }^{207} \mathrm{~Pb} /{ }^{206} \mathrm{~Pb}$ age of $1658 \pm 16 \mathrm{Ma}(n=$ $8, \mathrm{MSWD}=1.1$ ). The two ages are interpreted as dating separate episodes of xenotime growth.

ABDP9 75, 182.12-.25 m (Mount McRae Shale)

Five grains of monazite were analysed in this sample. All grains are platy, 100 to $200 \mu \mathrm{m}$ long, and poikiloblastic, with fine aligned inclusions aligned parallel to bedding in the host rock. Analyses contain around 100-600 ppm U and 400-4600 ppm Th. Excluding concordant analysis BR13-13A.1-3 with a ${ }^{207} \mathrm{~Pb} /{ }^{206} \mathrm{~Pb}$ age of $2317 \pm 25 \mathrm{Ma}(1 \sigma)$, analyses from all five grains define a single population with a ${ }^{207} \mathrm{~Pb} /{ }^{206} \mathrm{~Pb}$ age of $2211 \pm 8 \mathrm{Ma}(n=29$, MSWD $=1.3)$ (Fig. 3C; Table DR3). The outlier is equivalent in age to monazite grains in sample ABDP9 27B (see below), whereas the main population is equivalent in age to monazite in samples ABDP9 87B, ABDP9 44B and ABDP9 23A (see below).

\section{ABDP9 44B, 243.2-.3 m (Wittenoom Formation)}

From this sample, two poikiloblasts of monazite were analysed. The poikiloblasts are associated with fine felsic laminations in the host rock. Both grains are about $200 \mu \mathrm{m}$ long, platy and irregular, flattened and with inclusions aligned parallel to the laminations in the host rock. Analyses contain around 100-200 ppm U and 200-2600 ppm Th. All analyses yield a mean ${ }^{207} \mathrm{~Pb} /{ }^{206} \mathrm{~Pb}$ age of $2196 \pm 11$ $\mathrm{Ma}(n=11, \mathrm{MSWD}=0.4)($ Fig. 3D; Table DR4).

\section{ABDP9 27B, 333.42-.45 m (Wittenoom Formation)}

Within a $1 \mathrm{~mm}$ by $1 \mathrm{~mm}$ area of polished thin section, this sample contains three poikiloblasts of monazite, one of which lies adjacent to and in contact with a poikiloblast of xenotime. The monazite poikiloblasts are about $200 \mu \mathrm{m}$ across, irregular and rich in inclusions, some of which are aligned with bedding in the host sediment. Two of the poikiloblasts are connected by a thin plate of monazite with feathery outgrowths, $800 \mu \mathrm{m}$ long extending along bedding. Analysis spots were selected on the few areas larger than $10 \mu \mathrm{m}$ that are inclusion-free. Analyses on the monazite poikiloblasts contain 58-238 ppm U and 3-206 ppm Th, with variations of $\mathrm{Th} / \mathrm{U}$ from 0.01 to 3.4 within individual grains. These $\mathrm{Th}$ 
contents are unusually low compared to monazite from other samples. All analyses from the three monazite grains yield a mean ${ }^{207} \mathrm{~Pb} /{ }^{206} \mathrm{~Pb}$ age of $2307 \pm 15 \mathrm{Ma}(n=7$, MSWD = 0.7) (Fig. 3E; Table DR5).

The grain of xenotime is about $600 \mu \mathrm{m}$ by $300 \mu \mathrm{m}$, with an approximately blocky outline filled with fine dendritic and feathery outgrowths around a loosely consolidated core. A weak alignment with bedding is visible in the xenotime outgrowths. The xenotime is much richer in $U$ and Th than the monazite, containing around 900-2900 ppm $U$ and 400-2700 ppm Th, with $\mathrm{Th} / \mathrm{U}$ from 0.4 to 1.7. Excluding three concordant outliers with slightly younger ages, the remainder yielded a mean ${ }^{207} \mathrm{~Pb} /{ }^{206} \mathrm{~Pb}$ age of $2097 \pm 5 \mathrm{Ma}(n=12, \mathrm{MSWD}=0.6)$. The three younger analyses all derive from spots closer to the edges of the xenotime poikiloblast, and are equivalent in age, yielding a mean ${ }^{207} \mathrm{~Pb} /{ }^{206} \mathrm{~Pb}$ age of $2052 \pm 9 \mathrm{Ma}(n=3, \mathrm{MSWD}=0.3)($ Fig. 3E; Table DR5). The discrete age cluster is interpreted to represent the time of an overgrowth on the xenotime poikiloblast, and the age estimate is equivalent to that of a grain of xenotime in sample ABDP9 86A. Together, this sample records two or three episodes of unrelated phosphate growth, two in xenotime and one in monazite. The latter is equivalent in age with a single age outlier from monazite in sample ABDP9 75.

\section{ABDP9 23A, 363.03-.22 m (Wittenoom Formation)}

Five poikiloblastic grains of monazite were analysed in this sample (Fig. 3F; Table DR6). Grains are associated with fine $(<100 \mu \mathrm{m}$ thick) felsic laminations in the host rock, and are platy, aligned with the laminations, and rich in inclusions aligned with the laminations. Analyses yield U contents of about $90-$ $250 \mathrm{ppm}$ and Th contents of about 400-2000 ppm. Analyses on individual grains yielded variable age estimates. Analysis BR13-20B.1-3 yielded an imprecise age and is excluded from population analysis. Excluding another three, slightly younger analyses, the remaining data from four out of five grains yield a mean ${ }^{207} \mathrm{~Pb} /{ }^{206} \mathrm{~Pb}$ age of $2289 \pm 16 \mathrm{Ma}(n=11, \mathrm{MSWD}=1.4)$. The three younger outliers, each deriving from a separate grain, are equivalent in age with a mean ${ }^{207} \mathrm{~Pb} /{ }^{206} \mathrm{~Pb}$ age of $2195 \pm 21 \mathrm{Ma}(n=$ 3 , MSWD = 0.9). Two of these younger ages are from spots on the ends of platy monazite grains that yielded ca. $2289 \mathrm{Ma}$ ages. The younger age may represent a discrete stage of monazite overgrowth or modification on grains originally grown at ca. 2289 Ma. This is supported by equivalent ages of monazite in samples ABDP9 87B, ABDP9 75 and ABDP9 44B.

\section{DDH186, 183.0 m (Roy Hill Shale Member, Jeerinah Formation)}

Two large monazite porphyroblasts identified in this sample display elongate outlines (grain 1, $500 \mu \mathrm{m}$ by $200 \mu \mathrm{m}$; grain 2, $250 \mu \mathrm{m}$ by $100 \mu \mathrm{m}$ ) and are aligned in an overpressure vein. Both monazite porphyroblasts are enclosed in quartz and calcite. The crystals appear to be chemically homogeneous using BSE imaging, and contain rare mineral inclusions. A total of 22 analyses were obtained from the two monazite grains (Table DR7). One analysis, which has a high Th content (5480 ppm) and a Th/U ratio of 88 , yields discordant data that was excluded from pooled age calculation. The remaining analyses yield concordant or near-concordant data (Fig. 3G). Their $\mathrm{U}$ and Th concentrations range from 52-868 ppm and 16-4125 ppm, respectively, with $\mathrm{Th} / \mathrm{U}$ ratios between 0.1 and 16 (average 3.3). The most concordant analyses (within $\pm 5 \%$ disc.) have ${ }^{207} \mathrm{~Pb} /{ }^{206} \mathrm{~Pb}$ dates ranging from $2379 \mathrm{Ma}$ to $2438 \mathrm{Ma}$ with a weighted mean date of $2407 \pm 9 \mathrm{Ma}(n=18, \mathrm{MSWD}=0.68)$. If the three near-concordant $(6-7 \%$ disc.) analyses are included, a slightly more precise mean date is achieved: $2407 \pm 8 \mathrm{Ma}(n=21$, MSWD $=0.67$ ), which is regarded as the best estimate of the age of monazite growth. 


\section{References Cited}

Anbar, A.D., Duan, Y., Lyons, T.W., Arnold, G.L., Kendall, B., Creaser, R.A., Kaufman, A.J., Gordon, G.W., Scott, C., Garvin, J., and Buick, R., 2007, A whiff of oxygen before the Great Oxidation Event? Science, v. 317, p. 1903-1906.

Davy, R., and Hickman, A.H., 1988, The transition between the HamersIey and Fortescue Groups as evidenced in a drill core: Geological Survey of Western Australia Professional Paper, v. 23, p. 8597.

Fletcher, I.R., McNaughton, N.J., Aleinikoff, J.A., Rasmussen, B., and Kamo, S.L., 2004, Improved calibration procedures and new standards for $\mathrm{U}-\mathrm{Pb}$ and $\mathrm{Th}-\mathrm{Pb}$ dating of Phanerozoic xenotime by ion microprobe: Chemical Geology, v. 209, p. 295-314.

Fletcher, I.R., McNaughton, N.J., Davis, W.J., and Rasmussen, B., 2010, Matrix effects and calibration limitations in ion probe $\mathrm{U}-\mathrm{Pb}$ and $\mathrm{Th}-\mathrm{Pb}$ dating of monazite: Chemical Geology, v. 270, p. 31-44.

Fletcher, I.R., Rasmussen, B., and McNaughton, N.J., 2000, SHRIMP U-Pb geochronology of authigenic xenotime and its potential for dating sedimentary basins: Australian Journal of Earth Sciences, v. 47, p. 845-860.

Ludwig, K.R., 2008, Isoplot 3.6; a geochronology toolkit for Microsoft Excel: Berkeley Geochronology Center, $77 \mathrm{p}$.

Ludwig, K.R., 2009, Squid 2; a user's manual: Berkeley Geochronology Center, 100 p.

Rasmussen, B., Fletcher, I.R., and McNaughton, N.J., 2001, Dating low-grade metamorphic events by SHRIMP U-Pb analysis of monazite in shales: Geology, v. 29, p. 963-966.

Rasmussen, B., Fletcher, I.R., and Muhling, J.R., 2008, Pb/Pb geochronology, petrography and chemistry of Zr-rich accessory minerals (zirconolite, tranquillityite and baddeleyite) in mare basalt 10047: Geochimica et Cosmochimica Acta, v. 72, p. 5799-5818.

Stacey, J.S., and Kramers, J.D., 1975, Approximation of terrestrial lead isotope evolution by a twostage model: Earth and Planetary Science Letters, v. 26, p. 207-221.

Stern, R.A., and Rayner, N., 2003, Ages of several xenotime megacrysts by ID-TIMS: potential reference materials for ion microprobe $\mathrm{U}-\mathrm{Pb}$ geochronology: Geological Survey of Canada, Current Research 2003-F1, p. 1-7. 
Table DR1. U-Pb data for monazite in drill-hole ABDP9 (135.02-.10 m), Mount McRae Shale

\begin{tabular}{|c|c|c|c|c|c|c|c|c|c|c|c|c|c|}
\hline \multirow[b]{2}{*}{$\begin{array}{c}\text { Analysis } \\
\text { No. }\end{array}$} & \multirow[b]{2}{*}{$\begin{array}{c}\mathrm{U} \\
(\mathbf{p p m})\end{array}$} & \multirow[b]{2}{*}{$\begin{array}{c}\text { Th } \\
(\mathbf{p p m})\end{array}$} & \multirow[b]{2}{*}{$\begin{array}{c}\text { Th/ } \\
\text { U }\end{array}$} & \multirow[b]{2}{*}{$f_{206}(\%)$} & \multicolumn{3}{|c|}{${ }^{204} \mathrm{~Pb}$ corrected ratios } & \multicolumn{3}{|c|}{ Ages (Ma) } & \multirow[b]{2}{*}{$\begin{array}{l}{ }^{207} \mathrm{~Pb}^{*} \\
{ }^{206} \mathrm{~Pb}^{*}\end{array}$} & \multirow[b]{2}{*}{ \pm} & \multirow[b]{2}{*}{$\begin{array}{l}\text { Disc. } \\
(\%)\end{array}$} \\
\hline & & & & & $\begin{array}{r}{ }^{238} \mathrm{U} \\
\rho^{206} \mathrm{~Pb}\end{array}$ & \pm & $\begin{array}{l}{ }^{207} \mathrm{~Pb}^{*} \\
{ }^{206} \mathrm{~Pb}^{*}\end{array}$ & \pm & $\begin{array}{c}{ }^{238} \mathbf{U} \\
f^{206} \mathbf{P b}^{*}\end{array}$ & \pm & & & \\
\hline \multicolumn{14}{|c|}{ Grains in vein $(2192 \pm 24 \mathrm{Ma}, n=9$, MSWD $=1.00)$} \\
\hline 1320C.1-2 & 75 & 1332 & 18 & 0.17 & 2.642 & 0.042 & 0.1375 & 0.0020 & 2070 & 28 & 2195 & 26 & 6 \\
\hline 1320I.1-1 & 66 & 325 & 4.9 & 0.11 & 2.376 & 0.052 & 0.1362 & 0.0018 & 2265 & 42 & 2179 & 23 & -4 \\
\hline 1320I.1-2 & 54 & 649 & 12 & 0.26 & 2.518 & 0.049 & 0.1418 & 0.0042 & 2156 & 35 & 2249 & 51 & 4 \\
\hline 1320L.1-1 & 77 & 759 & 10 & 0.24 & 2.743 & 0.043 & 0.1375 & 0.0032 & 2004 & 27 & 2196 & 41 & 9 \\
\hline 1320L.1-2 & 68 & 1241 & 18 & 0.44 & 2.589 & 0.042 & 0.1384 & 0.0024 & 2105 & 29 & 2207 & 30 & 5 \\
\hline \multicolumn{14}{|c|}{ Grain in matrix $(2514 \pm 18 \mathrm{Ma}, n=2, \mathrm{MSWD}=0.67)$} \\
\hline 1320H.1-1 & 154 & 29840 & 194 & -0.06 & 2.172 & 0.028 & 0.1649 & 0.0013 & 2442 & 26 & 2507 & 13 & 3 \\
\hline $1320 \mathrm{H} .1-2$ & 190 & 42420 & 223 & -0.22 & 2.215 & 0.037 & 0.1664 & 0.0013 & 2402 & 34 & 2522 & 13 & 5 \\
\hline \multicolumn{14}{|c|}{ Rejected, disc. $>10 \%$} \\
\hline 1320C.1-1 & 59 & 359 & 6.1 & 0.00 & 2.762 & 0.050 & 0.1420 & 0.0022 & 1992 & 31 & 2252 & 27 & 12 \\
\hline
\end{tabular}

$\mathrm{Pb}^{*}$ indicate radiogenic $\mathrm{Pb}$

$f_{206}$ is the proportion of common (unradiogenic) $\mathrm{Pb}$ in ${ }^{206} \mathrm{~Pb}$, determined using the measured ${ }^{204} \mathrm{~Pb} /{ }^{206} \mathrm{~Pb}$ and a common $\mathrm{Pb}$ composition from the Stacey and Kramers (1975) model at the approximate age of the sample.

${ }^{238} \mathrm{U} /{ }^{206} \mathrm{~Pb}^{*}$ and ${ }^{207} \mathrm{~Pb}^{*}{ }^{206} \mathrm{~Pb}^{*}$ ratios and dates have been corrected for common $\mathrm{Pb}$.

Disc. is apparent discordance, as $\left.100\left(\mathrm{t}^{207} \mathrm{~Pb}^{*} /{ }^{206} \mathrm{~Pb} *\right]-\mathrm{t}\left[{ }^{238} \mathrm{U} /{ }^{206} \mathrm{~Pb}^{*}\right]\right) / \mathrm{t}\left[{ }^{207} \mathrm{~Pb}^{*} /{ }^{206} \mathrm{~Pb} *\right]$.

Analyses are sorted by descending $\left.\mathrm{t}^{207} \mathrm{~Pb}^{*}{ }^{206} \mathrm{~Pb}^{*}\right]$ except for those excluded in age calculation due to large discordance (and/or high common $\mathrm{Pb}$ ).

Session calibration precisions and external spot-to-spot errors provided in analytical procedures section.

Same footnotes apply to Tables DR2-7 
Table DR2. U-Pb data for xenotime in ABDP9 (141.87-.94 m), Mount McRae Shale

\begin{tabular}{|c|c|c|c|c|c|c|c|c|c|c|c|c|c|}
\hline \multirow[b]{2}{*}{$\begin{array}{c}\text { Analysis } \\
\text { No. }\end{array}$} & \multirow[b]{2}{*}{$\underset{(\text { ppm) }}{\mathrm{U}}$} & \multirow[b]{2}{*}{$\begin{array}{c}\text { Th } \\
(\mathbf{p p m})\end{array}$} & \multirow[b]{2}{*}{$\begin{array}{c}\mathbf{T h} / \\
\mathbf{U}\end{array}$} & \multirow[b]{2}{*}{$f_{206}(\%)$} & \multicolumn{3}{|c|}{${ }^{204} \mathrm{~Pb}$ corrected ratios } & \multicolumn{3}{|c|}{ Ages (Ma) } & \multirow[b]{2}{*}{$\begin{array}{l}{ }^{207} \mathrm{~Pb}^{*} \\
\rho^{206} \mathrm{~Pb}^{*}\end{array}$} & \multirow[b]{2}{*}{ \pm} & \multirow[b]{2}{*}{$\begin{array}{l}\text { Disc. } \\
(\%)\end{array}$} \\
\hline & & & & & $\begin{array}{c}{ }^{238} \mathrm{U} \\
{ }^{206} \mathrm{~Pb}\end{array}$ & \pm & $\begin{array}{l}{ }^{207} \mathrm{~Pb}^{*} \\
{ }^{206} \mathrm{~Pb}^{*}\end{array}$ & \pm & $\begin{array}{c}{ }^{238} \mathbf{U} \\
{ }^{206} \mathbf{P b}^{*}\end{array}$ & \pm & & & \\
\hline \multicolumn{14}{|c|}{ Older group $(2043 \pm 11 \mathrm{Ma}, n=6, \mathrm{MSWD}=0.79)$} \\
\hline 1313C.2-1 & 822 & 4160 & 5.2 & 0.03 & 2.684 & 0.057 & 0.1250 & 0.0014 & 2041 & 37 & 2029 & 20 & -1 \\
\hline 1313C.2-2 & 765 & 3964 & 5.4 & 0.11 & 2.698 & 0.058 & 0.1263 & 0.0009 & 2032 & 37 & 2048 & 12 & 1 \\
\hline 1313C.2-3 & 594 & 3513 & 6.1 & 0.10 & 2.757 & 0.063 & 0.1257 & 0.0017 & 1995 & 39 & 2039 & 24 & 3 \\
\hline $1313 C .2-4$ & 829 & 4133 & 5.1 & 0.03 & 2.661 & 0.057 & 0.1268 & 0.0008 & 2057 & 37 & 2054 & 11 & 0 \\
\hline $1313 C .2-5$ & 917 & 5098 & 5.7 & 0.08 & 2.882 & 0.059 & 0.1262 & 0.0008 & 1920 & 34 & 2046 & 11 & 7 \\
\hline 1313C.2-7 & 870 & 5021 & 6.0 & 0.08 & 2.986 & 0.077 & 0.1247 & 0.0009 & 1862 & 41 & 2025 & 12 & 9 \\
\hline \multicolumn{14}{|c|}{ Younger group $(1658 \pm 16 \mathrm{Ma}, n=8, \mathrm{MSWD}=1.14)$} \\
\hline 1313C.1-1 & 557 & 2724 & 5.1 & 0.03 & 3.448 & 0.080 & 0.1021 & 0.0010 & 1642 & 34 & 1663 & 17 & 1 \\
\hline 1313C.1-2 & 543 & 3155 & 6.0 & 0.03 & 3.509 & 0.081 & 0.1035 & 0.0010 & 1616 & 33 & 1688 & 17 & 5 \\
\hline $1313 C .1-3$ & 629 & 3613 & 5.9 & 0.06 & 3.370 & 0.076 & 0.1014 & 0.0016 & 1675 & 33 & 1651 & 29 & -2 \\
\hline 1313C.1-4 & 840 & 5304 & 6.5 & 0.18 & 3.525 & 0.076 & 0.0997 & 0.0014 & 1610 & 30 & 1618 & 26 & 1 \\
\hline 1313F.1-1 & 533 & 5419 & 11 & 0.49 & 3.402 & 0.079 & 0.1007 & 0.0015 & 1661 & 34 & 1638 & 28 & -2 \\
\hline 1313F.1-2 & 501 & 5590 & 12 & 0.04 & 3.507 & 0.083 & 0.1024 & 0.0011 & 1617 & 34 & 1668 & 19 & 3 \\
\hline 1313F.1-3 & 573 & 8558 & 15 & 0.34 & 3.500 & 0.081 & 0.1004 & 0.0018 & 1620 & 33 & 1631 & 32 & 1 \\
\hline 1313F.1-4 & 618 & 9007 & 15 & 0.85 & 3.313 & 0.076 & 0.1001 & 0.0017 & 1700 & 34 & 1626 & 32 & -5 \\
\hline \multicolumn{14}{|l|}{ Outlier } \\
\hline 1313C.2-6 & 783 & 4293 & 5.7 & 0.78 & 2.870 & 0.061 & 0.1202 & 0.0014 & 1927 & 35 & 1959 & 21 & 2 \\
\hline
\end{tabular}


Table DR3. U-Pb data for monazite in ABDP9 (182.12-.25 m), Mount McRae Shale

\begin{tabular}{|c|c|c|c|c|c|c|c|c|c|c|c|c|c|}
\hline \multirow[b]{2}{*}{$\begin{array}{c}\text { Analysis } \\
\text { No. }\end{array}$} & \multirow[b]{2}{*}{$\underset{(\mathbf{p p m})}{\mathbf{U}}$} & \multirow[b]{2}{*}{$\begin{array}{c}\text { Th } \\
\text { (ppm) }\end{array}$} & \multirow[b]{2}{*}{$\begin{array}{l}\mathbf{T h} / \\
\mathbf{U}\end{array}$} & \multirow[b]{2}{*}{$f_{206}(\%)$} & \multicolumn{3}{|c|}{${ }^{204} \mathrm{~Pb}$ corrected ratios } & \multicolumn{3}{|c|}{ Ages (Ma) } & \multirow[b]{2}{*}{$\begin{array}{l}{ }^{207} \mathrm{~Pb}^{*} \\
{ }^{206} \mathrm{~Pb}^{*}\end{array}$} & \multirow[b]{2}{*}{ \pm} & \multirow[b]{2}{*}{$\begin{array}{l}\text { Disc. } \\
\text { (\%) }\end{array}$} \\
\hline & & & & & $\begin{array}{l}{ }^{238} \mathrm{U} \\
\rho^{206} \mathrm{~Pb}\end{array}$ & \pm & $\begin{array}{l}{ }^{207} \mathrm{~Pb}^{*} \\
{ }^{206} \mathrm{~Pb}^{*}\end{array}$ & \pm & $\begin{array}{c}{ }^{238} \mathbf{U} \\
{ }^{206} \mathbf{P b}^{*}\end{array}$ & \pm & & & \\
\hline \multicolumn{14}{|c|}{ Older group $(2211 \pm 8 \mathrm{Ma}, n=29, \mathrm{MSWD}=1.3)$} \\
\hline 1313A.1-1 & 162 & 4558 & 28 & 0.03 & 2.493 & 0.043 & 0.1397 & 0.0014 & 2174 & 32 & 2223 & 18 & 2 \\
\hline 1313A.1-2 & 337 & 858 & 2.5 & 0.07 & 2.499 & 0.030 & 0.1360 & 0.0013 & 2170 & 22 & 2177 & 16 & 0 \\
\hline 1313A.1-4 & 261 & 1655 & 6.3 & 0.00 & 2.430 & 0.049 & 0.1400 & 0.0012 & 2222 & 37 & 2227 & 14 & 0 \\
\hline 1313A.1-5 & 226 & 3554 & 16 & 0.19 & 2.543 & 0.033 & 0.1335 & 0.0022 & 2138 & 24 & 2145 & 29 & 0 \\
\hline 1313A.2-1 & 201 & 2562 & 13 & 0.45 & 2.489 & 0.036 & 0.1338 & 0.0047 & 2177 & 26 & 2148 & 61 & -1 \\
\hline 1313A.2-2 & 118 & 2758 & 23 & 0.26 & 2.473 & 0.037 & 0.1357 & 0.0031 & 2189 & 28 & 2172 & 40 & -1 \\
\hline 1313A.2-3 & 207 & 1965 & 9.5 & -0.07 & 2.525 & 0.043 & 0.1387 & 0.0015 & 2151 & 31 & 2211 & 18 & 3 \\
\hline 1313A.2-4 & 208 & 1245 & 6.0 & 0.03 & 2.462 & 0.038 & 0.1400 & 0.0013 & 2197 & 29 & 2227 & 16 & 1 \\
\hline 1313A.2-5 & 416 & 388 & 0.9 & -0.03 & 2.395 & 0.028 & 0.1399 & 0.0010 & 2249 & 22 & 2225 & 13 & -1 \\
\hline 1313A.2-6 & 210 & 1571 & 7.5 & 0.23 & 2.469 & 0.032 & 0.1371 & 0.0015 & 2192 & 24 & 2190 & 20 & 0 \\
\hline 1313A.2-7 & 193 & 762 & 3.9 & -0.07 & 2.372 & 0.031 & 0.1391 & 0.0014 & 2268 & 25 & 2216 & 17 & -2 \\
\hline 1313B.1-1 & 191 & 692 & 3.6 & 0.03 & 2.436 & 0.032 & 0.1384 & 0.0014 & 2217 & 25 & 2208 & 17 & 0 \\
\hline 1313B.1-2 & 138 & 1403 & 10 & 0.09 & 2.320 & 0.040 & 0.1385 & 0.0015 & 2310 & 34 & 2208 & 19 & -5 \\
\hline 1313B.1-3 & 206 & 1031 & 5.0 & 0.20 & 2.418 & 0.041 & 0.1378 & 0.0015 & 2231 & 32 & 2200 & 19 & -1 \\
\hline 1313B.1-4 & 229 & 1692 & 7.4 & 0.07 & 2.393 & 0.040 & 0.1373 & 0.0013 & 2251 & 31 & 2193 & 17 & -3 \\
\hline 1313B.1-5 & 174 & 885 & 5.1 & 0.05 & 2.521 & 0.079 & 0.1399 & 0.0014 & 2154 & 57 & 2226 & 18 & 3 \\
\hline 1313B.1-6 & 111 & 1569 & 14 & 0.02 & 2.335 & 0.050 & 0.1398 & 0.0026 & 2297 & 41 & 2225 & 32 & -3 \\
\hline 1313D.1-1 & 511 & 574 & 1.1 & 0.06 & 2.544 & 0.029 & 0.1399 & 0.0010 & 2137 & 21 & 2226 & 12 & 4 \\
\hline 1313D.1-2 & 222 & 913 & 4.1 & 0.45 & 2.477 & 0.041 & 0.1380 & 0.0017 & 2186 & 31 & 2203 & 21 & 1 \\
\hline 1313D.1-3 & 237 & 1431 & 6.0 & 0.11 & 2.367 & 0.046 & 0.1374 & 0.0013 & 2272 & 37 & 2195 & 16 & -4 \\
\hline 1313D.1-4 & 584 & 1154 & 2.0 & 0.06 & 2.328 & 0.036 & 0.1407 & 0.0010 & 2304 & 30 & 2236 & 12 & -3 \\
\hline 1313D.1-5 & 286 & 665 & 2.3 & 0.12 & 2.470 & 0.050 & 0.1403 & 0.0013 & 2191 & 37 & 2231 & 16 & 2 \\
\hline 1313D.1-6 & 250 & 1724 & 6.9 & 0.01 & 2.377 & 0.039 & 0.1374 & 0.0012 & 2264 & 31 & 2195 & 16 & -3 \\
\hline 1313E.1-1 & 175 & 2740 & 16 & 0.04 & 2.579 & 0.051 & 0.1378 & 0.0016 & 2113 & 35 & 2199 & 20 & 4 \\
\hline 1313E.1-2 & 242 & 1727 & 7.1 & 0.13 & 2.611 & 0.043 & 0.1390 & 0.0014 & 2090 & 29 & 2214 & 17 & 6 \\
\hline 1313E.1-3 & 194 & 2289 & 12 & 0.31 & 2.537 & 0.051 & 0.1354 & 0.0017 & 2142 & 37 & 2169 & 21 & 1 \\
\hline 1313E.1-4 & 326 & 869 & 2.7 & 0.03 & 2.363 & 0.051 & 0.1399 & 0.0011 & 2275 & 41 & 2226 & 14 & -2 \\
\hline 1313E.1-5 & 405 & 1183 & 2.9 & 0.04 & 2.361 & 0.046 & 0.1377 & 0.0010 & 2276 & 38 & 2199 & 13 & -4 \\
\hline 1313E.1-6 & 164 & 1044 & 6.3 & 0.15 & 2.364 & 0.040 & 0.1376 & 0.0022 & 2274 & 32 & 2197 & 28 & -4 \\
\hline \multicolumn{14}{|l|}{ Outlier } \\
\hline 1313A.1-3 & 279 & 1238 & 4.4 & 0.19 & 2.254 & 0.028 & 0.1475 & 0.0021 & 2367 & 24 & 2317 & 25 & -2 \\
\hline
\end{tabular}


Table DR4. U-Pb data for monazite in ABDP9 (243.2-.3 m), Wittenoom Formation

\begin{tabular}{|c|c|c|c|c|c|c|c|c|c|c|c|c|c|}
\hline \multirow[b]{2}{*}{$\begin{array}{c}\text { Analysis } \\
\text { No. }\end{array}$} & \multirow[b]{2}{*}{$\begin{array}{c}\mathbf{U} \\
(\mathbf{p p m})\end{array}$} & \multirow[b]{2}{*}{$\begin{array}{c}\text { Th } \\
\text { (ppm) }\end{array}$} & \multirow[b]{2}{*}{$\begin{array}{c}\text { Th/ } \\
\mathbf{U}\end{array}$} & \multirow[b]{2}{*}{$f_{206}(\%)$} & \multicolumn{3}{|c|}{${ }^{204} \mathrm{~Pb}$ corrected ratios } & \multicolumn{3}{|c|}{ Ages (Ma) } & \multirow[b]{2}{*}{$\begin{array}{l}{ }^{207} \mathrm{~Pb}^{*} \\
{ }^{206} \mathrm{~Pb}^{*}\end{array}$} & \multirow[b]{2}{*}{ \pm} & \multirow[b]{2}{*}{$\begin{array}{l}\text { Disc. } \\
\text { (\%) }\end{array}$} \\
\hline & & & & & $\begin{array}{r}{ }^{238} \mathrm{U} \\
{ }^{206} \mathrm{~Pb}\end{array}$ & \pm & $\begin{array}{l}{ }^{207} \mathrm{~Pb}^{*} \\
{ }^{206} \mathrm{~Pb}^{*}\end{array}$ & \pm & $\begin{array}{c}{ }^{238} \mathrm{U} \\
{ }^{206} \mathrm{~Pb}^{*}\end{array}$ & \pm & & & \\
\hline \multicolumn{14}{|c|}{ Main group $(2196 \pm 11 \mathrm{Ma}, n=11, \mathrm{MSWD}=0.44)$} \\
\hline 1320E.1-1 & 167 & 383 & 2.3 & 0.02 & 2.660 & 0.034 & 0.1376 & 0.0012 & 2057 & 22 & 2198 & 15 & 6 \\
\hline 1320E.1-2 & 139 & 234 & 1.7 & 0.06 & 2.486 & 0.051 & 0.1361 & 0.0014 & 2179 & 38 & 2178 & 18 & 0 \\
\hline 1320E.1-3 & 116 & 1090 & 9.4 & 0.14 & 2.468 & 0.043 & 0.1376 & 0.0016 & 2193 & 32 & 2197 & 20 & 0 \\
\hline 1320E.1-4 & 129 & 831 & 6.4 & 0.26 & 2.539 & 0.061 & 0.1370 & 0.0031 & 2141 & 43 & 2190 & 39 & 2 \\
\hline 1320E.1-5 & 136 & 733 & 5.4 & 0.13 & 2.695 & 0.046 & 0.1384 & 0.0015 & 2035 & 29 & 2208 & 19 & 8 \\
\hline 1320E.1-6 & 201 & 330 & 1.6 & 0.01 & 2.493 & 0.040 & 0.1374 & 0.0011 & 2174 & 29 & 2194 & 14 & 1 \\
\hline 1320K.1-1 & 185 & 2579 & 14 & 0.18 & 2.762 & 0.060 & 0.1378 & 0.0016 & 1992 & 37 & 2199 & 20 & 9 \\
\hline 1320K.1-2 & 138 & 661 & 4.8 & 0.23 & 2.554 & 0.043 & 0.1364 & 0.0016 & 2130 & 31 & 2182 & 20 & 2 \\
\hline 1320K.1-3 & 131 & 1138 & 8.7 & 0.37 & 2.593 & 0.054 & 0.1360 & 0.0026 & 2103 & 37 & 2177 & 33 & 3 \\
\hline 1320K.1-4 & 180 & 752 & 4.2 & -0.04 & 2.616 & 0.053 & 0.1394 & 0.0013 & 2087 & 36 & 2219 & 17 & 6 \\
\hline 1320K.1-5 & 124 & 799 & 6.5 & 0.06 & 2.547 & 0.044 & 0.1372 & 0.0015 & 2135 & 31 & 2192 & 19 & 3 \\
\hline
\end{tabular}


Table DR5. U-Pb data for monazite and xenotime in ABDP9 (333.42-.45 m), Wittenoom Formation

\begin{tabular}{|c|c|c|c|c|c|c|c|c|c|c|c|c|c|}
\hline \multirow[b]{2}{*}{$\begin{array}{c}\text { Analysis } \\
\text { No. }\end{array}$} & \multirow[b]{2}{*}{$\begin{array}{c}\mathbf{U} \\
(\mathbf{p p m})\end{array}$} & \multirow[b]{2}{*}{$\begin{array}{c}\text { Th } \\
\text { (ppm) }\end{array}$} & \multirow[b]{2}{*}{$\begin{array}{c}\text { Th/ } \\
\mathbf{U}\end{array}$} & \multirow[b]{2}{*}{$f_{206}(\%)$} & \multicolumn{3}{|c|}{${ }^{204} \mathrm{~Pb}$ corrected ratios } & \multicolumn{3}{|c|}{ Ages (Ma) } & \multirow[b]{2}{*}{$\begin{array}{l}{ }^{207} \mathrm{~Pb}^{*} \\
{ }^{206} \mathrm{~Pb}^{*}\end{array}$} & \multirow[b]{2}{*}{ \pm} & \multirow[b]{2}{*}{$\begin{array}{l}\text { Disc. } \\
(\%)\end{array}$} \\
\hline & & & & & $\begin{array}{c}{ }^{238} \mathbf{U} \\
{ }^{206} \mathbf{P b}\end{array}$ & \pm & $\begin{array}{l}{ }^{207} \mathrm{~Pb}^{*} \\
{ }^{206} \mathrm{~Pb}^{*}\end{array}$ & \pm & $\begin{array}{c}{ }^{238} \mathrm{U} \\
{ }^{206} \mathrm{~Pb}^{*}\end{array}$ & \pm & & & \\
\hline \multicolumn{14}{|c|}{ Monazite $(2307 \pm 15 \mathrm{Ma}, n=7, \mathrm{MSWD}=0.72)$} \\
\hline 1320F.1-1 & 58 & 4 & 0.1 & 0.28 & 2.246 & 0.043 & 0.1495 & 0.0038 & 2374 & 38 & 2340 & 43 & -1 \\
\hline 1320F.1-2 & 159 & 74 & 0.5 & 0.06 & 2.335 & 0.030 & 0.1471 & 0.0012 & 2298 & 25 & 2312 & 14 & 1 \\
\hline 1320F.1-3 & 101 & 10 & 0.1 & 0.32 & 2.384 & 0.048 & 0.1471 & 0.0021 & 2258 & 38 & 2312 & 24 & 2 \\
\hline 1320F.2-1 & 238 & 3 & 0.0 & 0.06 & 2.332 & 0.028 & 0.1445 & 0.0016 & 2300 & 23 & 2281 & 19 & -1 \\
\hline 1320F.2-2 & 192 & 66 & 0.3 & -0.02 & 2.229 & 0.028 & 0.1462 & 0.0011 & 2390 & 25 & 2302 & 13 & -4 \\
\hline 1320F.2-3 & 61 & 206 & 3.4 & 0.47 & 2.363 & 0.041 & 0.1499 & 0.0027 & 2275 & 33 & 2345 & 31 & 3 \\
\hline 1320F.3-1 & 67 & 70 & 1.0 & 0.73 & 2.278 & 0.036 & 0.1473 & 0.0026 & 2346 & 31 & 2315 & 31 & -1 \\
\hline \multicolumn{14}{|c|}{ Xenotime older group $(2097 \pm 5 \mathrm{Ma}, n=12, \mathrm{MSWD}=0.59)$} \\
\hline $1320 \mathrm{~F} .1-1$ & 1289 & 883 & 0.7 & -0.03 & 2.565 & 0.049 & 0.1303 & 0.0006 & 2122 & 34 & 2102 & 8 & -1 \\
\hline 1320F.1-2 & 1025 & 517 & 0.5 & -0.01 & 2.643 & 0.052 & 0.1296 & 0.0006 & 2069 & 35 & 2092 & 9 & 1 \\
\hline 1320F.1-3 & 1439 & 818 & 0.6 & 0.03 & 2.606 & 0.050 & 0.1303 & 0.0006 & 2094 & 34 & 2103 & 8 & 1 \\
\hline 1320F.1-4 & 938 & 437 & 0.5 & 0.02 & 2.675 & 0.063 & 0.1307 & 0.0012 & 2047 & 41 & 2107 & 16 & 3 \\
\hline 1320F.1-5 & 1596 & 595 & 0.4 & 0.03 & 2.620 & 0.049 & 0.1300 & 0.0005 & 2084 & 33 & 2099 & 7 & 1 \\
\hline 1320F.1-7 & 1748 & 990 & 0.6 & 0.01 & 2.598 & 0.048 & 0.1291 & 0.0005 & 2099 & 33 & 2085 & 7 & -1 \\
\hline 1320F.1-8 & 1867 & 1380 & 0.8 & 0.03 & 2.616 & 0.048 & 0.1300 & 0.0005 & 2087 & 33 & 2097 & 7 & 1 \\
\hline 1320F.1-10 & 2639 & 2257 & 0.9 & 0.02 & 2.516 & 0.045 & 0.1297 & 0.0004 & 2157 & 33 & 2094 & 5 & -4 \\
\hline 1320F.1-11 & 1629 & 552 & 0.3 & 0.01 & 2.580 & 0.048 & 0.1300 & 0.0005 & 2112 & 33 & 2098 & 7 & -1 \\
\hline 1320F.1-12 & 1806 & 804 & 0.5 & -0.01 & 2.647 & 0.048 & 0.1305 & 0.0005 & 2066 & 32 & 2104 & 6 & 2 \\
\hline 1320F.1-13 & 2372 & 2567 & 1.1 & 0.01 & 2.530 & 0.046 & 0.1298 & 0.0005 & 2147 & 33 & 2095 & 6 & -3 \\
\hline 1320F.1-15 & 2840 & 2538 & 0.9 & 0.00 & 2.480 & 0.044 & 0.1297 & 0.0008 & 2184 & 33 & 2094 & 11 & -5 \\
\hline \multicolumn{14}{|c|}{ Xenotime younger group $(2052 \pm 9 \mathrm{Ma}, n=3, \mathrm{MSWD}=0.27)$} \\
\hline $1320 F .1-6$ & 1636 & 2694 & 1.7 & 0.05 & 2.565 & 0.048 & 0.1266 & 0.0005 & 2122 & 34 & 2051 & 7 & -4 \\
\hline 1320F.1-9 & 1902 & 694 & 0.4 & 0.01 & 2.630 & 0.048 & 0.1268 & 0.0005 & 2077 & 33 & 2054 & 7 & -1 \\
\hline 1320F.1-14 & 1827 & 892 & 0.5 & 0.06 & 2.589 & 0.049 & 0.1261 & 0.0009 & 2106 & 34 & 2044 & 12 & -4 \\
\hline
\end{tabular}


Table DR6. U-Pb data for monazite in ABDP9 (363.03-.22 m), Wittenoom Formation

\begin{tabular}{|c|c|c|c|c|c|c|c|c|c|c|c|c|c|}
\hline \multirow[b]{2}{*}{$\begin{array}{c}\text { Analysis } \\
\text { No. }\end{array}$} & \multirow[b]{2}{*}{$\underset{(\mathbf{p p m})}{\mathbf{U}}$} & \multirow[b]{2}{*}{$\begin{array}{c}\text { Th } \\
\text { (ppm) }\end{array}$} & \multirow[b]{2}{*}{$\begin{array}{c}\text { Th/ } \\
\mathbf{U}\end{array}$} & \multirow[b]{2}{*}{$f_{206}(\%)$} & \multicolumn{3}{|c|}{${ }^{204} \mathrm{~Pb}$ corrected ratios } & \multicolumn{3}{|c|}{ Ages (Ma) } & \multirow[b]{2}{*}{$\begin{array}{l}{ }^{207} \mathrm{~Pb}^{*} \\
{ }^{206} \mathrm{~Pb}^{*}\end{array}$} & \multirow[b]{2}{*}{ \pm} & \multirow[b]{2}{*}{$\begin{array}{l}\text { Disc. } \\
\text { (\%) }\end{array}$} \\
\hline & & & & & $\begin{array}{c}{ }^{238} \mathbf{U} \\
\rho^{206} \mathbf{P b}^{*}\end{array}$ & \pm & $\begin{array}{l}{ }^{207} \mathrm{~Pb}^{*} \\
{ }^{206} \mathrm{~Pb}^{*}\end{array}$ & \pm & $\begin{array}{c}{ }^{238} \mathbf{U} \\
{ }^{206} \mathbf{P b}^{*}\end{array}$ & \pm & & & \\
\hline \multicolumn{14}{|c|}{ Older group $(2289 \pm 16 \mathrm{Ma}, n=11, \mathrm{MSWD}=1.4)$} \\
\hline 1320A.1-1 & 119 & 1457 & 12 & 0.01 & 2.367 & 0.031 & 0.1467 & 0.0020 & 2272 & 25 & 2308 & 24 & 2 \\
\hline 1320A.1-2 & 102 & 1069 & 10 & 0.02 & 2.530 & 0.052 & 0.1448 & 0.0016 & 2147 & 38 & 2285 & 19 & 6 \\
\hline 1320A.1-3 & 93 & 1787 & 19 & 0.08 & 2.395 & 0.042 & 0.1417 & 0.0016 & 2249 & 33 & 2249 & 19 & 0 \\
\hline 1320B.1-1 & 100 & 932 & 9.3 & 0.36 & 2.460 & 0.035 & 0.1439 & 0.0018 & 2199 & 26 & 2275 & 22 & 3 \\
\hline 1320B.1-2 & 123 & 584 & 4.8 & 0.41 & 2.387 & 0.040 & 0.1457 & 0.0021 & 2256 & 32 & 2296 & 25 & 2 \\
\hline 1320B.1-5 & 89 & 1551 & 17 & 0.34 & 2.439 & 0.044 & 0.1453 & 0.0020 & 2215 & 33 & 2291 & 24 & 3 \\
\hline 1320B.1-6 & 140 & 345 & 2.5 & 0.04 & 2.477 & 0.051 & 0.1474 & 0.0013 & 2186 & 38 & 2316 & 15 & 6 \\
\hline 1320D.2-1 & 108 & 669 & 6.2 & 0.51 & 2.406 & 0.034 & 0.1431 & 0.0018 & 2241 & 27 & 2265 & 22 & 1 \\
\hline 1320J.1-1 & 123 & 922 & 7.5 & 0.15 & 2.403 & 0.049 & 0.1435 & 0.0014 & 2243 & 39 & 2270 & 17 & 1 \\
\hline 1320J.1-2 & 103 & 2006 & 19 & 0.00 & 2.452 & 0.052 & 0.1477 & 0.0015 & 2205 & 39 & 2320 & 18 & 5 \\
\hline 1320J.1-3 & 90 & 557 & 6.2 & 0.75 & 2.537 & 0.047 & 0.1457 & 0.0024 & 2142 & 34 & 2296 & 28 & 7 \\
\hline \multicolumn{14}{|c|}{ Younger group $(2195 \pm 21 \mathrm{Ma}, n=3, \mathrm{MSWD}=0.87)$} \\
\hline 1320B.1-4 & 249 & 426 & 1.7 & 0.14 & 2.443 & 0.038 & 0.1367 & 0.0011 & 2212 & 29 & 2186 & 14 & -1 \\
\hline 1320D.1-1 & 96 & 454 & 4.7 & 0.18 & 2.499 & 0.036 & 0.1394 & 0.0017 & 2170 & 27 & 2219 & 22 & 2 \\
\hline 1320J.1-4 & 121 & 792 & 6.6 & 0.02 & 2.423 & 0.057 & 0.1369 & 0.0024 & 2227 & 44 & 2188 & 30 & -2 \\
\hline
\end{tabular}


Table DR7. U-Pb data for monazite in DDH186 (183.0 m), Roy Hill Shale Member

\begin{tabular}{|c|c|c|c|c|c|c|c|c|c|c|c|c|c|}
\hline \multirow[b]{2}{*}{$\begin{array}{c}\text { Analysis } \\
\text { No. }\end{array}$} & \multirow[b]{2}{*}{$\underset{(\mathbf{p p m})}{\mathbf{U}}$} & \multirow[b]{2}{*}{$\begin{array}{c}\text { Th } \\
\text { (ppm) }\end{array}$} & \multirow[b]{2}{*}{$\begin{array}{c}\mathbf{T h} / \\
\mathbf{U} /\end{array}$} & \multirow[b]{2}{*}{$f_{206}(\%)$} & \multicolumn{3}{|c|}{${ }^{204} \mathrm{~Pb}$ corrected ratios } & \multicolumn{3}{|c|}{ Ages (Ma) } & \multirow[b]{2}{*}{$\begin{array}{l}{ }^{207} \mathrm{~Pb}^{*} \\
{ }^{206} \mathrm{~Pb}^{*}\end{array}$} & \multirow[b]{2}{*}{ \pm} & \multirow[b]{2}{*}{$\begin{array}{l}\text { Disc. } \\
\text { (\%) }\end{array}$} \\
\hline & & & & & $\begin{array}{l}{ }^{238} \mathbf{U} \\
f^{206} \mathbf{P b}^{*}\end{array}$ & \pm & $\begin{array}{l}{ }^{207} \mathrm{~Pb}^{*} \\
{ }^{206} \mathrm{~Pb}^{*}\end{array}$ & \pm & $\begin{array}{c}{ }^{238} \mathbf{U} \\
\rho^{206} \mathbf{P b}^{*}\end{array}$ & \pm & & & \\
\hline \multicolumn{14}{|c|}{ Main group $(2407 \pm 8 \mathrm{Ma}, n=21$, MSWD $=0.67)$} \\
\hline 1902D.1-1 & 116 & 345 & 3.0 & 0.07 & 2.108 & 0.059 & 0.1542 & 0.0021 & 2503 & 58 & 2393 & 23 & -5 \\
\hline 1902C.1-15 & 182 & 190 & 1.0 & 0.06 & 2.155 & 0.046 & 0.1538 & 0.0018 & 2457 & 43 & 2389 & 20 & -3 \\
\hline 1902C.1-10 & 643 & 231 & 0.4 & 0.18 & 2.161 & 0.039 & 0.1544 & 0.0017 & 2452 & 37 & 2396 & 19 & -2 \\
\hline 1902C.1-16 & 221 & 202 & 0.9 & -0.08 & 2.162 & 0.040 & 0.1549 & 0.0015 & 2451 & 37 & 2400 & 17 & -2 \\
\hline 1902C.1-6 & 250 & 1207 & 4.8 & 0.06 & 2.165 & 0.047 & 0.1548 & 0.0014 & 2448 & 44 & 2399 & 16 & -2 \\
\hline 1902C.1-4 & 266 & 299 & 1.1 & 0.35 & 2.195 & 0.041 & 0.1529 & 0.0030 & 2420 & 38 & 2379 & 34 & -2 \\
\hline 1902D.1-3 & 214 & 1127 & 5.3 & 0.11 & 2.193 & 0.031 & 0.1535 & 0.0016 & 2422 & 29 & 2385 & 18 & -2 \\
\hline 1902C.1-14 & 212 & 116 & 0.5 & 0.18 & 2.183 & 0.040 & 0.1546 & 0.0019 & 2431 & 37 & 2397 & 21 & -1 \\
\hline 1902C.1-5 & 283 & 250 & 0.9 & 0.11 & 2.151 & 0.050 & 0.1577 & 0.0016 & 2461 & 48 & 2431 & 17 & -1 \\
\hline 1902C.1-7 & 393 & 225 & 0.6 & 0.17 & 2.189 & 0.052 & 0.1564 & 0.0016 & 2426 & 48 & 2417 & 18 & 0 \\
\hline 1902C.1-1 & 225 & 635 & 2.8 & -0.06 & 2.182 & 0.049 & 0.1574 & 0.0015 & 2432 & 46 & 2428 & 16 & 0 \\
\hline 1902C.1-3 & 252 & 4125 & 16 & 0.13 & 2.187 & 0.042 & 0.1570 & 0.0016 & 2427 & 39 & 2424 & 18 & 0 \\
\hline 1902C.1-13 & 164 & 16 & 0.1 & 0.19 & 2.201 & 0.046 & 0.1560 & 0.0020 & 2414 & 42 & 2413 & 22 & 0 \\
\hline 1902D.1-2 & 57 & 739 & 13 & -0.16 & 2.181 & 0.047 & 0.1583 & 0.0032 & 2433 & 43 & 2438 & 34 & 0 \\
\hline 1902C.1-12 & 695 & 110 & 0.2 & 0.18 & 2.276 & 0.028 & 0.1538 & 0.0016 & 2348 & 24 & 2388 & 18 & 2 \\
\hline 1902D.1-4 & 282 & 1032 & 3.7 & 0.09 & 2.251 & 0.030 & 0.1558 & 0.0014 & 2369 & 27 & 2411 & 16 & 2 \\
\hline 1902D.1-5 & 52 & 148 & 2.8 & 0.18 & 2.272 & 0.055 & 0.1555 & 0.0036 & 2352 & 47 & 2407 & 39 & 2 \\
\hline 1902D.1-6 & 125 & 339 & 2.7 & -0.08 & 2.274 & 0.039 & 0.1561 & 0.0022 & 2349 & 33 & 2414 & 24 & 3 \\
\hline 1902C.1-9 & 868 & 1989 & 2.3 & 0.05 & 2.061 & 0.036 & 0.1553 & 0.0009 & 2550 & 36 & 2405 & 10 & -6 \\
\hline 1902C.1-8 & 242 & 1407 & 5.8 & 0.03 & 2.356 & 0.046 & 0.1574 & 0.0017 & 2280 & 37 & 2428 & 18 & 6 \\
\hline 1902C.1-11 & 679 & 226 & 0.3 & 0.10 & 2.427 & 0.044 & 0.1544 & 0.0015 & 2225 & 34 & 2395 & 16 & 7 \\
\hline \multicolumn{14}{|l|}{ Rejected } \\
\hline 1902C.1-2 & 63 & 5484 & 88 & 0.11 & 2.464 & 0.057 & 0.1745 & 0.0038 & 2196 & 43 & 2602 & 36 & 16 \\
\hline
\end{tabular}

